\title{
NEW ANTIBIOTICS 4181-A AND B FROM STREPTOMYCES \\ GRISEUS; TAXONOMY, FERMENTATION, ISOLATION AND CHARACTERIZATION
}

\author{
Toshio Otani, Ichiro Yamawaki, Hiroshi Matsumoto, \\ YOSHINORI Minami, YuJi Yamada \\ and Teruyoshi MarunaKa \\ Biological Research Laboratory, Taiho Pharmaceutical Co., Ltd., \\ Kawauchi-cho, Tokushima 771-01, Japan \\ Chang-Qing Qi, Tie Tian, Rui Zhang, Mei-Yu XIE \\ and JING-RONG LU \\ Institute of Medicinal Biotechnology, Chinese Academy of Medical Sciences, \\ Beijing, People's Republic of China
}

(Received for publication August 26, 1987)

\begin{abstract}
The new antibiotics 4181-A and B were isolated from the fermentation broth of Streptomyces griseus, a soil isolate. Their molecular formulae were determined as $\mathrm{C}_{29} \mathrm{H}_{21} \mathrm{NO}_{9}$ and $\mathrm{C}_{28} \mathrm{H}_{19} \mathrm{NO}_{2}$, respectively. The UV, IR and NMR spectra suggest that they possess a quinone moiety in their structures. They were found to have antibacterial, antifungal and antitumor activity.
\end{abstract}

In the course of our screening for new antibiotics from actinomycetes, antimicrobial and antitumor antibiotics, 4181-A and B, were isolated by extraction with ethyl acetate from both culture broth and mycelia of Streptomyces griseus, newly isolated from a soil sample. The present paper deals with the taxonomy of the producing strain 4181 , the fermentation, isolation and physico-chemical and biological properties of the antibiotics.

\section{Taxonomy of the Producing Strain 4181}

The strain 4181 was isolated from a soil sample collected at Emei Mountain in Sichuan Province, China. Taxonomic properties were determined according to the method of the International Streptomyces Project (ISP) ${ }^{1)}$ using the media recommended by WAKSMAN ${ }^{22}$.

Microscopic observation showed the aerial mycelium to be generally straight to flexious and mature spore chain had 8 to 40 or more spores per chain. The spores were cylindrical in shape with smooth surface, as shown in Plate 1. No scleotia, sporangia or flagellated spores were observed.

The cultural characteristics of strain 4181 on various media are shown in Table 1. Aerial mycelium was often poorly developed and mass

Plate 1. Electron micrograph of the spores of strain 4181.

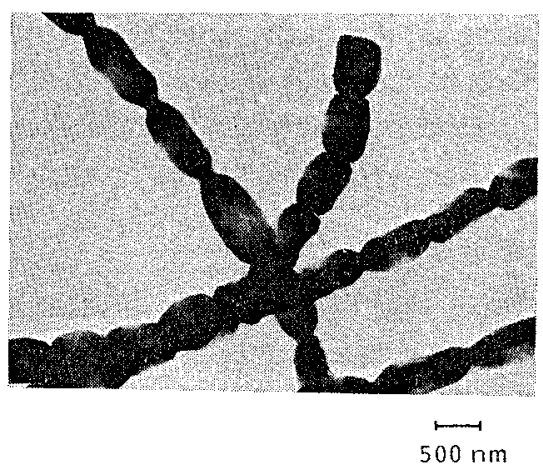


Table 1. Cultural characteristics of strain 4181 .

\begin{tabular}{|c|c|c|c|c|}
\hline Medium & Growth & Aerial mycelium & Reverse side & $\begin{array}{c}\text { Soluble } \\
\text { pigment }\end{array}$ \\
\hline Sucrose - nitrate agar & Good & Light gray & Dark olive & None \\
\hline Glucose - asparagine agar & Moderate & Whitish & Light yellow & None \\
\hline Nutrient agar & Moderate & None & Light yellow & None \\
\hline BENNET's agar & Moderate & None & Pale yellowish brown & None \\
\hline $\begin{array}{l}\text { Yeast extract - malt } \\
\text { extract agar } \\
\text { (ISP medium No. 2) }\end{array}$ & Moderate & Grayish white & Pale yellowish brown & None \\
\hline $\begin{array}{l}\text { Oatmeal agar } \\
\text { (ISP medium No. 3) }\end{array}$ & Good & Grayish & Dull yellow & None \\
\hline $\begin{array}{l}\text { Inorganic salts - starch agar } \\
\text { (ISP medium No. 4) }\end{array}$ & Poor & None & Colorless & None \\
\hline $\begin{array}{l}\text { Glycerol - asparagine agar } \\
\text { (ISP medium No. 5) }\end{array}$ & Moderate & $\begin{array}{l}\text { Light yellowish gray } \\
\sim \text { light gray }\end{array}$ & Dark olive & None \\
\hline $\begin{array}{l}\text { Tyrosine agar } \\
\quad \text { (ISP medium No. 7) }\end{array}$ & Good & Light gray & Olive black & None \\
\hline
\end{tabular}

Color names were assigned according to Guide to Color Standard (Nippon Shikisai Co., Ltd., Tokyo, 1981).

color was almost light gray on some media tested. The vegetative mycelium developed well without fragmentation on most of the media and was usually pale yellowish brown to dark olive or olive black (Table 1). Melanoid pigment was not produced on peptone - yeast extract - iron agar or tyrosine agar.

The physiological properties of strain 4181 are shown in Table 2. The utilization of carbon
Table 2. Physiological properties of strain 4181 .

\begin{tabular}{lc}
\hline Optimum temperature for growth & $27 \sim 30^{\circ} \mathrm{C}$ \\
Melanin production & - \\
Starch hydrolysis & + \\
Milk coagulation & + \\
Milk peptonization & + \\
Gelatin liquefaction $\left(27^{\circ} \mathrm{C}\right)$ & + (weakly) \\
Nitrate reduction & - \\
$\mathrm{H}_{2} \mathrm{~S}$ production & - \\
\hline &
\end{tabular}
sources by this strain was examined according to the methods of Pridham and GotTLIEB ${ }^{3)}$. D-Glucose, L-arabinose, D-xylose, inositol, D-mannitol, D-fructose, rhamnose, sucrose, raffinose, D-mannose, maltose, D-sorbitol, inuline and sodium citrate were found to be utilized for growth. Chemical analysis of whole-cell hydrolysate by the procedure of BECKER et al. ${ }^{4)}$ revealed the presence of LL-diaminopimelic acid and glycine.

The taxonomic studies indicated that strain 4181 belongs to the genus Streptomyces. The characteristics of strain 4181 were compared with the published description of various Streptomyces in the approved lists of bacterial names ${ }^{57}$ and subsequent species published validly. It was considered strain 4181 to be closely related to a member of $S$. griseus $^{8}$. Therefore, strain 4181 was classified as a strain of S. griseus, named S. griseus 4181. This strain has been deposited at the Fermentation Research Institute, Agency of Industrial Science and Technology, Japan, as Streptomyces sp. 4181 with accession number of FERM BP-1010.

\section{Fermentation}

The antimicrobial activity was determined by the agar well method using Staphylococcus aureus FDA 209P and Micrococcus luteus ATCC 9341 as test organisms. The organisms were also used for bioautography.

The parent strain 4181 spontaneously decreased in its ability to produce antibiotics after several 
times transplantation and thereafter selection of a high-producing strain was examined by monospore isolation. The antibiotic low-producing variant lost simultaneously its ability to produce yellowish brown to dark olive pigment in the fermentation broth. The high-yield variant selected was used throughout the fermentation experiments.

The stock culture of $S$. griseus 4181 was maintained in lyophilized tubes of $10 \%$ skim milk and the working cultures were grown on inorganic salts - starch agar slant (ISP medium No. 4). Loopful spores and mycelia from a 2 weeks-old slant were inoculated into $100 \mathrm{ml}$ of the seed medium in a 500-ml Erlenmeyer flask, and incubated at $27^{\circ} \mathrm{C}$ for 2 days on a rotary shaker at $220 \mathrm{rpm}(3.5 \mathrm{~cm}-$ stroke). The seed medium consisted of glucose $0.1 \%$, soluble starch $2.4 \%$, Polypeptone $0.1 \%$, beef extract $0.3 \%$, yeast extract $0.5 \%$ and $\mathrm{CaCO}_{3} 0.3 \%$, pH 7.0 . Four $\mathrm{ml}(4 \%)$ of this seed culture were transferred to $100 \mathrm{ml}$ of the fermentation medium in a 500-ml Erlenmeyer flask containing glycerol $4.0 \%$, Pharmamedia $1.0 \%, \mathrm{NaCl} 0.2 \%, \mathrm{MgSO}_{4} \cdot 7 \mathrm{H}_{2} \mathrm{O} 0.2 \%$ and $\mathrm{CaCO}_{3} 0.3 \%$, pH 7.0. The fermentation was carried out at $27^{\circ} \mathrm{C}$ for 4 days on a rotary shaker at $220 \mathrm{rpm}(3.5 \mathrm{~cm}$-stroke).

\section{Isolation and Purification}

After the fermentation was carried out, the fermentation broth ( 25 liters) was centrifuged to separate the mycelium from the broth. The mycelial cake was extracted three times with methanol, and the methanol extract was concentrated to a small volume. This concentrate was adjusted to $\mathrm{pH} 3$ and extracted twice with ethyl acetate. The broth filtrate was also adjusted to $\mathrm{pH} 3$ and extracted twice with ethyl acetate. The ethyl acetate layers were combined, washed with water, dried with anhydrous $\mathrm{Na}_{2} \mathrm{SO}_{4}$ and evaporated to a suitable volume. To the ethyl acetate solution, $n$-hexane was added to obtain the precipitate containing antibiotics. The precipitate was collected by centrifugation, and dried in vacuo to yield a dark brown powder $(6.32 \mathrm{~g})$. This crude powder was dissolved in chloroform and subjected to silica gel column chromatography. The column was successively developed with chloroform and chloroform - methanol (50:1 and 20:1).

Most of antibiotic 4181-A was eluted as a major component with chloroform. The active fractions containing antibiotic 4181-A were combined, concentrated to dryness, and further purified by recrystallization from a mixture of chloroform and acetone to give an orange powder $(733 \mathrm{mg})$. The fractions of antibiotic 4181-B, eluted with a mixture of chloroform and methanol $(20: 1)$ as a minor component, were concentrated to dryness and subsequently obtained as a reddish orange powder $(218 \mathrm{mg})$ after recrystallization from a mixture of chloroform and methanol.

The preparation of antibiotics 4181-A and B were analyzed by HPLC to determine their purity under the following conditions: Column, $\mu$ Bondapak CN $(150 \times 3.9 \mathrm{~mm}$ i.d. $)$; mobile phase, (a) $n$-hexane - acetic acid - chloroform $(195: 5: 100)$ and (b) $(95: 5: 100)$; flow rate, 1.5 $\mathrm{ml} /$ minute; detector, $U V$ at $254 \mathrm{~nm}$. The respective retention times of antibiotics $4181-\mathrm{A}$ and $\mathrm{B}$ were 4.6 and $c a .44$ minutes with mobile phase (a) and were 1.7 and 6.5 minutes with mobile phase (b).

\section{Physico-chemical Properties}

Both of the antibiotics 4181-A and B were

Fig. 1. UV spectra of 4181-A and $\mathrm{B}$ (in $\mathrm{CHCl}_{3}$ ).

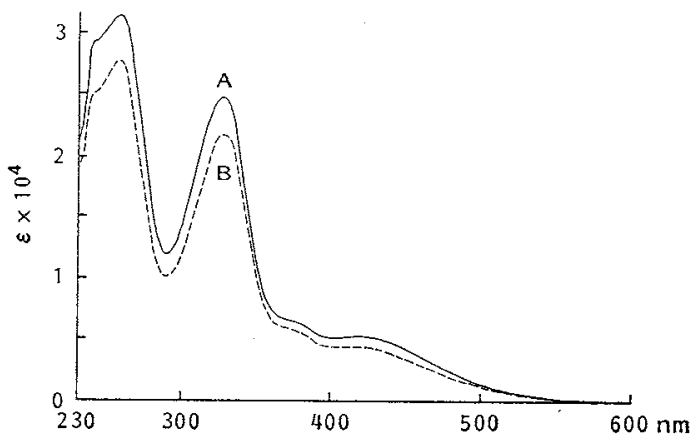


acidic and slightly soluble in chloroform, methanol, ethyl acetate and dimethylsulfoxide, and insoluble in water, $n$-hexane and ethyl ether. The molecular formula of antibiotics 4181-A and $\mathrm{B}$ were determined as $\mathrm{C}_{28} \mathrm{H}_{21} \mathrm{NO}_{2}$ and $\mathrm{C}_{28} \mathrm{H}_{19} \mathrm{NO}_{2}$ from elemental analysis and the molecular weight determination by fast atom bombardment mass spectrometry (FAB-MS). The ions observed in FAB-MS of these antibiotics are probably the quasi-molecular ions of $(\mathrm{M}+1)^{+}$for respective hydroquinone forms ${ }^{7)}$. The UV and IR spectra of antibiotics 4181-A and B are shown in Figs. 1 and 2, respectively. The characteristic ketone absorption observed at $1686 \mathrm{~cm}^{-1}$ (or $1680 \mathrm{~cm}^{-1}$ ) in IR spectra suggests that

Fig. 2. IR spectra of 4181-A and $\mathrm{B}(\mathrm{KBr})$.

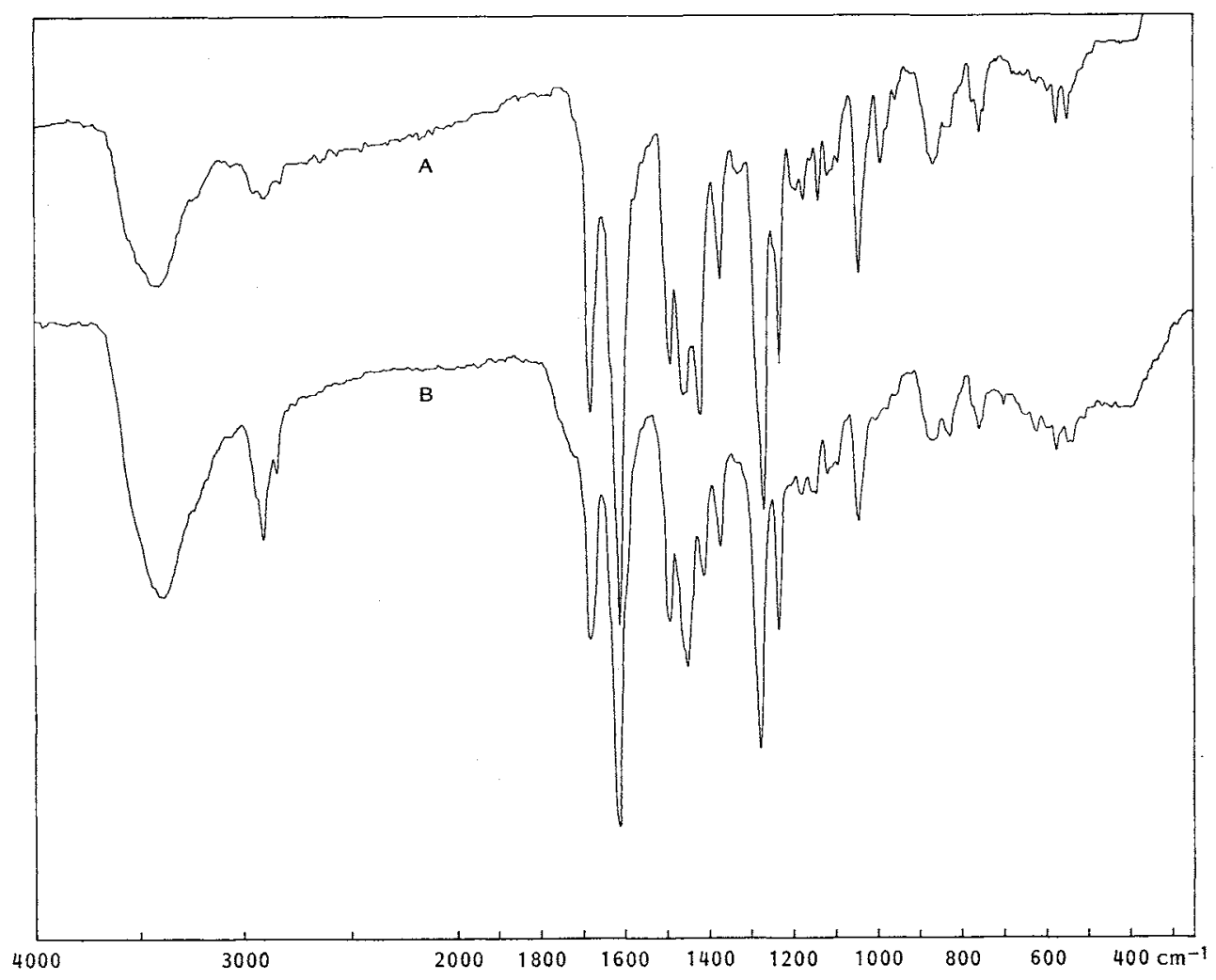

Table 3. Physico-chemical properties of 4181-A and B.

\begin{tabular}{|c|c|c|}
\hline & $4181-\mathrm{A}$ & $4181-B$ \\
\hline Appearance & Orange powder & Reddish orange powder \\
\hline $\mathrm{MP}\left({ }^{\circ} \mathrm{C}, \mathrm{dec}\right)$ & $>300$ & $>260$ \\
\hline Molecular formula & $\mathrm{C}_{29} \mathrm{H}_{21} \mathrm{NO}_{9}$ & $\mathrm{C}_{88} \mathrm{H}_{19} \mathrm{NO}_{9}$ \\
\hline Elemental analysis & C 65.48, H 4.36, N 2.58 . & C 63.45, H 5.57 , N 1.91. \\
\hline FAB-MS $(m / z)$ & $\begin{array}{l}530.147(\mathrm{MHQ}+1)^{+} \\
(\text {calcd } 530.149)\end{array}$ & $\begin{array}{l}516.134(\mathrm{MHQ}+1)^{+} \\
\text {(calcd } 516.139)\end{array}$ \\
\hline $\mathrm{UV} \lambda_{\mathrm{max}}^{\mathrm{CHCl}_{3}} \mathrm{~nm}(\varepsilon)$ & $\begin{array}{l}258(31,000), 327(24,800), \\
376(\mathrm{sh}, 6,650), 418(5,330)\end{array}$ & $\begin{array}{l}258(22,700), 327(18,000) \\
377(\mathrm{sh}, 5,220), 418(3,770)\end{array}$ \\
\hline IR $\nu_{\mathrm{m} . \mathrm{ax}}^{\mathrm{KBr}} \mathrm{cm}^{-1}$ & $\begin{array}{l}3430,1686,1621,1468,1461 \\
1425,1278,1238\end{array}$ & $\begin{array}{l}3400,1680,1612,1489,1450, \\
1411,1278,1231\end{array}$ \\
\hline Rf value* & 0.39 & 0.07 \\
\hline
\end{tabular}

* Silica gel TLC: $\mathrm{CHCl}_{3}-\mathrm{MeOH}(40: 1)$. 
these compounds belong to quinone antibiotics. The ${ }^{1} \mathrm{H}$ NMR spectrum of antibiotic 4181-A, shown in Table 4, indicates the presence of five aromatic protons $(\delta 7.4 \sim 8.2)$, two methoxy groups $(\delta 3.92$ and 3.99) and one aromatic hydroxyl group $(\delta 14.00)$, together with three methylene groups and a tertiary methyl group. Antibiotic 4181-B is closely related to 4181-A, except for an aromatic hydroxyl group instead of a methoxy group in the ${ }^{1} \mathrm{H}$ NMR spectrum. These results as well as other physico-chemical properties of antibiotics 4181-A and B are summarized in Table 3.

Biological Properties

Antimicrobial activity was determined by serial agar-dilution method using Nutrient agar for bacteria and Sabouraud agar for yeast and filamentous fungi. MICs were exhibited in terms of $\mu \mathrm{g} / \mathrm{ml}$ after overnight-incubation at $37^{\circ} \mathrm{C}$ for bacteria and after incubation for $48 \sim 72$ hours

Table 4. ${ }^{1} \mathrm{H}$ NMR data of $4181-\mathrm{A}$ and B (in DMSO$d_{6}, 100 \mathrm{MHz}$ ).

\begin{tabular}{llc}
\hline & \multicolumn{1}{c}{$4181-\mathrm{A}$} & $4181-\mathrm{B}$ \\
\hline Aromatic $\mathrm{OH}$ & $14.00(1 \mathrm{H}, \mathrm{s})$ & $13.98(1 \mathrm{H}, \mathrm{s})$, \\
& & $10.14(1 \mathrm{H}, \mathrm{s})$ \\
Aromatic H & $8.15(2 \mathrm{H}, \mathrm{s})$, & $8.13(2 \mathrm{H}, \mathrm{s})$, \\
& $7.46(3 \mathrm{H}, \mathrm{s})$ & $7.43(1 \mathrm{H}, \mathrm{s})$, \\
& & $7.42(1 \mathrm{H}, \mathrm{s})$, \\
& & $7.40(1 \mathrm{H}, \mathrm{s})$ \\
$\mathrm{OCH}_{3}$ & $3.99(3 \mathrm{H}, \mathrm{s})$, & $3.98(3 \mathrm{H}, \mathrm{s})$ \\
$\mathrm{CH}_{2}$ & $3.92(3 \mathrm{H}, \mathrm{s})$ & \\
& $4.24(2 \mathrm{H}, \mathrm{br} \mathrm{t})$, & $4.23(2 \mathrm{H}, \mathrm{br} \mathrm{t})$, \\
& $4.0 \sim 3.6$ & $3.9 \sim 3.6$ \\
& $(2 \mathrm{H}, \mathrm{m})$, & $(2 \mathrm{H}, \mathrm{m})$, \\
$\mathrm{CH}_{3}$ & $3.37(2 \mathrm{H}, \mathrm{br} \mathrm{s})$ & $3.35(2 \mathrm{H}, \mathrm{br} \mathrm{s})$ \\
& $1.35(3 \mathrm{H}, \mathrm{s})$ & $1.35(3 \mathrm{H}, \mathrm{s})$ \\
\hline
\end{tabular}

Table 5. Antimicrobial spectra of 4181-A and B.

\begin{tabular}{|c|c|c|}
\hline \multirow{2}{*}{ Test organisms } & \multicolumn{2}{|c|}{$\operatorname{MIC}(\mu \mathrm{g} / \mathrm{ml})$} \\
\hline & $4181-\mathrm{A}$ & $4181-B$ \\
\hline Staphylococcus aureus FDA 209P & 6.25 & $<0.2$ \\
\hline Micrococcus luteus ATCC 10240 & 25 & $<0.2$ \\
\hline M. luteus ATCC 9341 & 100 & $<0.2$ \\
\hline Bacillus subtilis ATCC 6633 & 6.25 & $<0.2$ \\
\hline Streptococcus feacalis subsp. & 3.13 & $<0.2$ \\
\hline Mycobacterium smegmatis ATCC 607 & 100 & 100 \\
\hline Escherichia coli B IFO 13168 & $>100$ & 1.56 \\
\hline Proteus vulgaris IFO 3849 & $>100$ & 1.56 \\
\hline Klebsiella pneumoniae ATCC 10031 & $>100$ & 3.13 \\
\hline Salmonella typhimurium & $>100$ & 6.25 \\
\hline Serratia marcescens IFO 12648 & $>100$ & 3.13 \\
\hline Pseudomonas aeruginosa IFO 13275 & $>100$ & 6.25 \\
\hline Citrobacter freundii IFO 12681 & $>100$ & 6.25 \\
\hline Enterobacter cloacae IFO 13535 & $>100$ & 6.25 \\
\hline Acinetobacter calcoaceticus IFO 12552 & $>100$ & 3.13 \\
\hline Flavobacterium meningosepticum IFO 12235 & $>100$ & 0.39 \\
\hline Candida albicans IFO 1061 & 0.78 & 0.39 \\
\hline C. utilis IAM 4220 & 0.78 & 0.78 \\
\hline C. krusei IFO 0011 & 3.13 & 3.13 \\
\hline Saccharomyces delbrueckii IAM 12236 & 0.78 & 1.56 \\
\hline Rhodotorula rubra & 1.56 & 1.56 \\
\hline Pichia farinosa IFO 0193 & 3.13 & 3.13 \\
\hline Aspergillus niger IFO 6341 & $>100$ & 3.13 \\
\hline Penicillium notatum IFO 4640 & $>100$ & 1.56 \\
\hline Trichophyton mentagrophytes IFO 5466 & 100 & 0.78 \\
\hline Sclerotinia sclerotiorum IFO 4876 & 100 & 1.56 \\
\hline Mucor racemosus Fresenius f. racemosus IFO 4581 & 100 & 0.78 \\
\hline Arthroderma tuberculatum IFO 8165 & 50 & 1.56 \\
\hline
\end{tabular}


at $27^{\circ} \mathrm{C}$ for yeast and filamentous fungi. The antimicrobial spectra of 4181-A and B are shown in Table 5. As shown in the table, the antibiotic 4181-A has activity against Gram-positive bacteria, but not against Gram-negative bacteria. Antibiotic 4181-B showed strong antibacterial activity against a wide variety of Gram-positive and Gram-negative bacteria, and higher activity against Gram-positive bacteria compared to antibiotic 4181-A. Antibiotic 4181-B showed strong antifungal activity, but antibiotic 4181-A was less active against filamentous fungi.

The cytocidal activity of antibiotics $4181-\mathrm{A}$ and $\mathrm{B}$ was examined on $\mathrm{KB}$ cells in vitro. When the cells were exposed to the antibiotic for 3 days, the $\mathrm{ED}_{50}$ values of antibiotics $4181-\mathrm{A}$ and $\mathrm{B}$ were 0.003 $\mu \mathrm{g} / \mathrm{ml}$ and $0.005 \mu \mathrm{g} / \mathrm{ml}$, respectively.

Antitumor activity of antibiotics 4181-A and B was evaluated by prolongation of median survival time of mice bearing P388 leukemia. Antibiotics were administered intraperitoneally on day 1 and on day 1, 5 and 9 in $\mathrm{BDF}_{1}$ mice. The antibiotics exhibited antitumor activity at a dose range of 5 to $40 \mathrm{mg} / \mathrm{kg} /$ day for $4181-\mathrm{A}$ and 0.625 to $5 \mathrm{mg} / \mathrm{kg} /$ day for $4181-\mathrm{B}$. After intraperitoneal administration of $40 \mathrm{mg} / \mathrm{kg}$ of these antibiotics, the $d d \mathrm{Y}$ mice did not show any symptoms of toxicity.

\section{Discussion}

The physico-chemical and biological properties of antibiotics 4181-A and B were compared with those of known antibiotics. Recently, OMURA et al.$^{8,99}$ reported the antibacterial and anti-mycoplasmal antibiotics, cervinomycins. The spectral data of antibiotic 4181-A were very similar to those of cervinomycin $\mathrm{A}_{2}$. Cervinomycin $\mathrm{A}_{2}$ was reported to determine the molecular formula by high-resolution electron impact mass spectrometry (EI-MS), whereas the EI-MS of antibiotic 4181-A gave no characteristic ion peaks because of its less volatility.

The molecular formula of antibiotic 4181- $\left(\mathrm{C}_{28} \mathrm{H}_{19} \mathrm{NO}_{9}\right)$ was found to differ only by $\mathrm{CH}_{2}$ with that of 4181-A $\left(\mathrm{C}_{28} \mathrm{H}_{21} \mathrm{NO}_{s}\right)$. The ${ }^{1} \mathrm{H}$ NMR spectra showed antibiotic 4181-B to have one methoxy and two aromatic hydroxyl groups, while 4181-A showed two methoxy and one aromatic hydroxyl groups in their structures. Cervinomycin $A_{2}$ has been reported to be inactive against fungi and to have no antitumor activity, but antibiotics 4181 -A and $B$ to show antibacterial, antifungal and antitumor activity. Their biological properties differ from those of cervinomycins. Therefore, antibiotics $4181-A$ and $B$ is considered to be new antibiotics.

Detailed studies on the structures and antitumor activity of these antibiotics will be reported elsewhere.

\section{Acknowledgments}

The authors are indebted to Professor M. NAKaYama of University of Osaka Prefecture and Dr. M. Hamada of Institute of Microbial Chemistry for their valuable comments and suggestions during the course of this study.

\section{References}

1) Shirling, E. B. \& D. Gotrueb: Methods for characterization of Streptomyces species. Int. J. Syst. Bacteriol. 16: 313 340, 1966

2) Waksman, S. A. $(E d$.$) : The Actinomycetes. Classification, Identification and Description of Genera$ and Species. Vol. 2. Williams \& Wilkins Co., Baltimore, 1961

3) Pridham, T. G. \& D. Gotrlieb: The utilization of carbon compounds by some Actinomycetales as an aid for species determination. J. Bacteriol. 56: 107 114, 1948

4) BeCKer, B.; M. P. Lechevalier, R. E. Gordon \& H. A. Lechevalier: Rapid differentiation between Nocardia and Streptomyces by paper chromatography of whole-cell hydrolysates. Appl. Microbiol. 12: $421 \sim 423,1964$

5) Skerman, V. B. D.; V. McGowan \& P. H. A. SNeath: Approved lists of bacterial names. Int. J. Syst. Bacteriol. 30: 225 420, 1980 
6) Kutzner, H. J.: The family Streptomycetaceae. In The Prokaryotes, Vol. II. Ed., M.P. STARR et al., pp. 2028 2098, Springer Verlag, Heidelberg, 1982

7) COOPER, R. \& S. UNGER: Structure of the quinone antibiotic EM5519 and the behavior of quinones in fast atom bombardment mass spectrometry. J. Antibiotics 38: 24 30, 1985

8) Ōmura, S.; Y. Iwai, K. Hinotozawa, Y. Takahashi, J. Kato, A. Nakagawa, A. Hirano, H. Shimizu \& K. HANEDA: Cervinomycin $\mathrm{A}_{1}$ and $\mathrm{A}_{2}$, new antibiotics active against anaerobes, produced by Streptomyces cervinus sp. nov. J. Antibiotics 35: 645 652, 1982

9) ÖMURA, S.; A. NAKAGAWA, K. KUSHIDA \& G. LuKACS: Structure of cervinomycin, a novel antianaerobic antibiotic. J. Am. Chem. Soc. 108: 6088 6089, 1986 